\title{
Weight Gain of Seaweed Kappaphycus alvarezii (Rhodophyta, Solierisceae) and Sargassum polycystum (Paeophyta, Sargassaceae) Mix Cultured at Different Planting Distances
}

Rajuddin Syamsuddin ${ }^{1}$, Ridwan Bohari², Saparuddin ${ }^{2}$

${ }^{1}$ Center of Excellence for Development and Utilization of Seaweed, Hasanuddin University (PUI-P2R-UNHAS), Makassar, Indonesia

${ }^{2}$ Faculty of Marine Science and Fisheries, Hasanuddin University, Indonesia

\section{ABSTRACT}

This study was conducted to analyze the weight of Kappaphycus alvarezzi and Sargassum polycystum mixcultured at different planting distances. Statistical analyses showed that planting distance was significantly influence the growth of Kalvarezzi and $S$. polycystum. Difference in weight gain between both species be due to the difference in their morphology which affect water motion and nutrient uptake. Higher weight gain of $S$. polycycstum was obtained at wider planting distance $(35 \mathrm{~cm})$. High, and at $30 \mathrm{~cm}$ for K.alvarezii. K.alvarezii was more susceptible to competition for the environmental factors compared to $S$. polycycstum. Higher weight gain of K.alvarezii obtained in this mix-culture with S.polycystum compared to the K.alvarezii which was singly cultured by previously several workers.

Keywords : Mix-Culture, Planting Distance, Weight Gain, Water Quality Parameters, K. Alvarezii, S. Polycystum.

\section{INTRODUCTION}

The macroscopic marine algae Rhodophyceae (red algae) and Phaeophyceae (brown algae) are among the economically important marine natural resources of Indonesia and other tropical countries. They are commercial important seaweeds developed to supply local and global market as carrageenan and algin(ate) sources. Of hundreds seaweeds species, Kappaphycus alvarezii (Carrageenophytes) and Sargassum polycystum (Alginophytes) were exported recently.

Sargassum polycystum is cultivated for alginate, as emulsifier, thickener, stabilizer, and gel-forming agent in food industries. It is naturally growth in wave protected and coral reef area. In Indonesia. this brown seaweed is not yet popularly cultivated by the coastal communties. The most widely cultivated is K.alvarezii.

With their high commercial value and facts that both species naturally grow side by side in the sea, K.alvarezii and S.polycystum were tried to be cultivated together, and analyze the effect of spacing between the two on their growth.

\section{METHODS AND MATERIAL}

\section{STUDY SITE AND TIME}

The study was conducted on July 13 - September 7, 2016 at Jonggoa Waters, Batu-batu Village, District of Galesong Utara, Takalar Regency, 15 miles southward Makassar City, South Sulawesi Province, Indonesia. 


\section{CULTURE METHOD}

Longline with bambo raft as frame was the culture method applied. $K$. alvarezii and $S$. polycystum (Figure 1) seeds were obtained locally at the study area. As much as 25 grams of $K$. alvarezii and $S$. polycystum seeds were tied intermittently at the longline ropes.

\section{EXPERIMENTAL DESIGN}

Randomized Complete Design was experimental design applied. Planting distances $25 \mathrm{~cm}, 30 \mathrm{~cm}$, and $35 \mathrm{~cm}$ between $K$. alvarezii with $S$.polycystum were the treatments tried, each with three replicates.

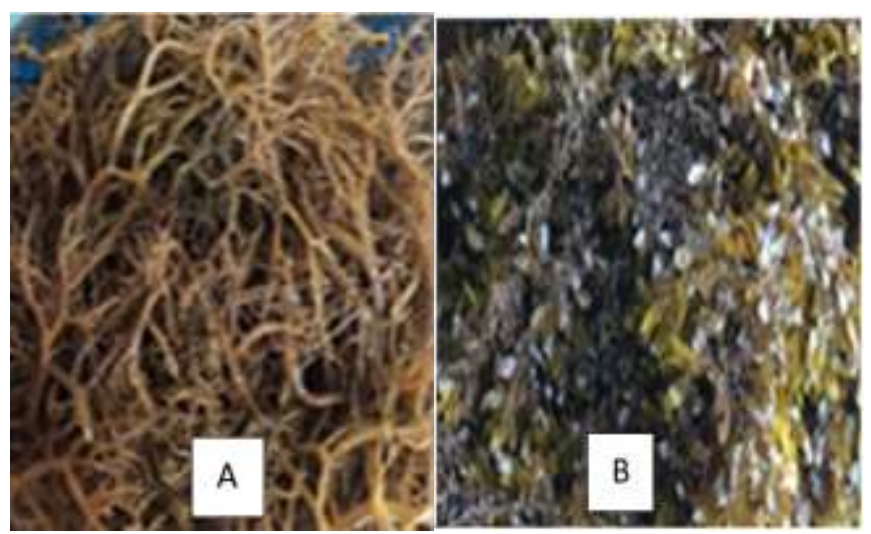

Figure 1. K.alvarezii (A) and S.polycystum (B)

\section{PARAMETERS}

Weight gain was computed at the end of stdy using the following formula :

$\mathrm{W}=\mathrm{Wt}-\mathrm{Wo} ; \mathrm{W}=$ weight gain $(\mathrm{g})$

$\mathrm{Wt}=$ final weight of seaweed $(\mathrm{g})$

Wo $=$ initial weight of seaweed $(\mathrm{g})$

Water quality parameters were analysed at the Water Quality Laboratory, Faculty of Marine Sciences and Fisheries, Hasanuddin University, Makassar, Indonesia. Water temperature, salinity, and current speed were measured daily using thermomemer, handrefractomete, and current meter respectively.
Nitrate, ammonium, and phosphate concentrations were anlysed at the begining, the middle, and at the end of the experiment using spectrophometer.

\section{DATA ANALYSIS}

The weight gain data was statistically analysed using the Analysis of Variance (ANOVA) continued with W-Tukey. Water quality parameteres were descriptively analysed using table and references.

\section{RESULTS AND DISCUSSION}

\section{RESULTS}

Analysis of Variance (Anova) showed that with mix culture of $K$. alvarezii and $S$. polycystum, planting distance was significantly influence $(p<0,05)$ the weight gain of both species. WTuckey Test showed highest weight gain $(810.00 \pm 166.469 \mathrm{~g})$ of $K$. alvarezii was recorded at $30 \mathrm{~cm}$ which was not significantly different with at $35 \mathrm{~cm}$ planting distance $(458.67 \pm 150.487 \mathrm{~g})$. Both weight gain were significantly higher compared to weight gain of $142.67 \pm 314.87 \mathrm{~g}$, at 25 $\mathrm{cm}$ planting distance (Figure 2).

Highest weight gain $(1409 \pm 242.57 \mathrm{~g})$ of $S$. polycystum was obtained at 35 planting distance, which was not significantly different with $1074.20 .66 \mathrm{~g}$ the weight gain at $30 \mathrm{~cm}$ planting distance, but higher than weight gain at $25 \mathrm{~cm}$ distance.

Weight gain range of $142.67 \pm 314.874 \mathrm{~g}$ $810.00 \pm 166.469 \mathrm{~g}$ of K.alvarezii in this experiment was higher compared to the range of 186.23$340.80 \mathrm{~g}$ recorded by Wenno (2014) and $114-192$ g (Alimuddin, 2011) of K.alvarezii cultured singly at the same location.

Weight gain of $S$. polycystum was relatively higher $\quad(861.67 \pm 146.95 \mathrm{~g} \quad-\quad 1409 \pm 242.57 \mathrm{~g})$ 
compared to $K$. alvarezii $(142.67 \pm 314.87 \mathrm{~g}$ $810.00 \pm 166.469 \mathrm{~g}$ ), at al planting distances.

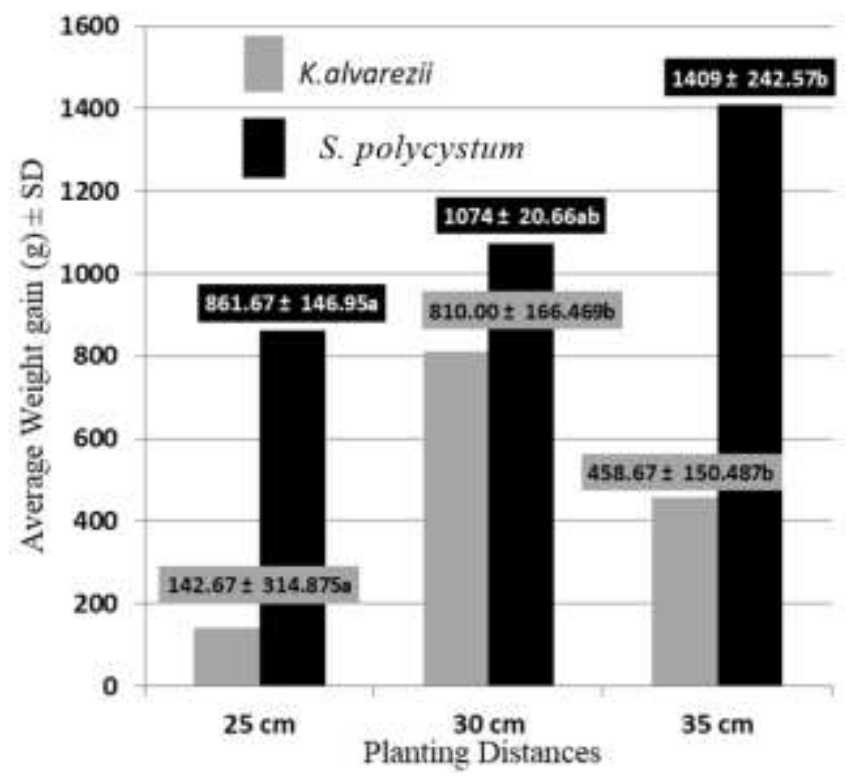

Figure 2. Weight Gain of K.alvarezii and S. Polycycstum at Different Planting Distances

\section{DISCUSSION}

Differences in weight gain of K.alvarezii and $S$. polycycstum at different planting distance possibly due to intraspecific competition of each species. Eah of this macroalga is susceptible to competition for water motion which influence nutrient kinetics (Harrison and Hurd, 2001; Kotiya, et.al., 2011; Edward and Connel, 2012), space, and light when these resources are in short supply in coastal ecosystems (Edward and Connel, 2012), although water current of 0,03-0,2 $\mathrm{m} / \mathrm{s}$ in this study was suitable for both seaweed growth (Anggadiredja et al.,2008). The physiological and morphological differences between each species cause difference in response to the impact of different spacing then different in absorbing nutrients which in turn cause difference in the growth of the species. Higher weight gain of $S$. polycycstum was obtained at wider planting distance $(35 \mathrm{~cm})$ because of reduction the thickness of boundary layer between the water and thalli due to stronger water movement between the thallus.
Acceleration the diffusion of nutrients into thalli cause these conditions (Neish 2005). This nutrient uptake was accounted for $81-98 \%$ of the variation in weight gain of K.alvarezii (Glenn and Doty, 1992). In strong water movements condition that lift sedimentary particles onto the water surface 1 waters on the experimental site, S.polycystum thalli was protected from dirts and silt deposition (Sudjiharno, 2001) cause more nutrients carried by water current and absorbed by plants (Prihaningrum, et al 2001) as well as higher photosynthesis rate resulting higher weight gain of this species. Instead of at wider (35 $\mathrm{cm}$ ) planting distances, higher weight gain of K.alvarezii obtained at $30 \mathrm{~cm}$. This indicated that K.alvarezii was more susceptible to competition for the environmental factors compared to S. polycycstum.

More efficiently in uptaking nutrient via mass transport (Hurd et al. 1997) and in absorbing light (for photosynthesis and nutrients uptake) of S.polycystum caused its higher weight gain (Endo et., al., 2013) than K.alvarezii due to leafy and blady thallus canopy of S.polycystum (Endo et., al., 2013). Higher weight gain of K.alvarezii obtained in this mix-culture with S.polycystum compared to the K.alvarezii singly cultured by previously several workers, could be attributed to shading effect of thallus and phlorotannins content of brown algae S.polycystum (Hwang et.al., 2004) which prevent attacks of herbivores that often attack K.alvarezii. The existence of phenols, the phlorotannins which form a complex with alginic acid of the cell wall (of the brown algae) (Singh and Sidana, 2014) is soluble in water (Maina, 2014), was diffused (exuded into the surrounding water media) by passing through the cell wall (Carlson and Mayer, 1983; Schoenwaelder and Clayton, 1998; Arnold and Targett, 2002; Koivikko et al., 2005) then was absorbed by K.alvarezii thallus, further react with both proteinaceous and carbohydrate substances of the seaweed thallus (Swanson and Druehl, 2002). This compound 
perform the roles as chemical defenses (herbivore deterrents, antibacterial agents, and UV screens) (Hwang et.al., 2004; Singh and Sidana, 2014; Kadam et.al., 2015), deterring herbivores out from the lush canopy (Swanson and Druehl, 2002; Hwang et.al., .2004; Amsler and Fairhead, 2006) of $K$.alvarezii, avoided the plant from bacterial infection (Kim and Wijesekara, 2011; Swamy, 2011; Singh and Sidana, 2014), help protect the algae against other predators and epiphytes (Ragan and Jansen, 1978), antifouling substances (Steinberg, 2011), protected the red algae from stress conditions (Kim and Wijesekara, 2011), such as inluence of UV radiation (Swanson and Druehl, 2002; Kim and Wijesekara, 2011). Together with the antibiotics and hormones contained in the brown seaweed thallus, these compunds synergically preventing the red seaweed from ice-ice bacteria and promoted the growth.

Nitrogen and phosphorous determine the growth (Neish and Shacklock, 1971; Neish et al, 1977; DeBoer, 1979; Lapointe and Ryther, 1979; , Rui et al. 1990; Chow, 2012), and the biochemical composition of algae (Michelon et.al, 2016). Although concentration of ammonium (0,06 - 0,12 $\mathrm{mg} / \mathrm{L})$ lower than nitrate $(0,23-0,32 \mathrm{mg} / \mathrm{L})$, absorption of ammonium is more important than nitrate (Dy and Yap 2001; Raikar and Wafar 2006). However both were considered to be in optimal concentrations for the seaweeds growth (Zatnika, 2009). Nitrogen metabolism in macroalgae is closely linked to photosynthetic carbon metabolism (Vergara et al., 1998). Phosphate concentration at $0,09-1,80 \mathrm{ppm}$ was laso suitable for seaweed growth (Ditjenkan Budidaya, 2005).

Recorded water temperature $\left(28-30^{\circ} \mathrm{C}\right)$ during the experiment (July to September) seems to be optimal for growth of $S$. polycycstum (Onho and Orosco, 1987; Angadiredja, et al, 2008), and optimal for $K$. alvarezii growth is $24-30^{\circ} \mathrm{C}$ (Glenn and
Doty, 1990), although rather beyond the temperature for rapid increase in growth of $S$. polycycstum (22 to $28^{\circ} \mathrm{C}$ ) that was at normally prevails from September to December/January at Visakhapatnam, East Coast of India (Rao and Rao, 2002).

Recorded salinity range of 35 - $37 \mathrm{gL}^{-1}$ was optimal for the growth of K. Alvarezii (Neish, 2005), and for $S$. polycycstum which was exhibited in the range of $20-40 \mathrm{~g} / \mathrm{L}$, and maximum growth was occurred at $32 \mathrm{~g} / \mathrm{L}$ (Xiao zou et.al. 2017

\section{CONCLUSION}

Difference in term of weight gain (growth rate) between both species could be due to the difference in their morphology, which may have effects nutrient uptake. Highest weight gain of $K$. alvarezii and $S$. polycystum was recorded at $30 \mathrm{~cm}$ and at 35 planting distance, respectively. This could be related to water motion between the plants, which influence nutrient uptake kinetics.

Higher weight gain of $S$. polycycstum was obtained at wider planting distance $(35 \mathrm{~cm})$. Instead of at wider $(35 \mathrm{~cm})$ planting distances, higher weight gain of K.alvarezii obtained at $30 \mathrm{~cm}$. This indicated that K.alvarezii was more susceptible to competition for the environmental factors compared to $S$. polycycstum. Higher weight gain of Kalvarezii obtained in this mixculture with S.polycystum compared to the K.alvarezii which was singly cultured by previously several workers, could be attributed to shading effect of thallus and phlorotannins content of brown algae S.polycystum. Recorded water qiality parameters were optimal for both species growth. 


\section{ACKNOWLEDGEMENT}

The authors gratefully thank the support of the Ministry of Research, Technology and Higher Education of the Republic of Indonesia through the World Class Professor program (no. 168.A10/D2/KP/2017). Thank you and appreciation for the Center of Excellence for Development and Utilization of Seaweed, Hasanuddin University (PUIP2R-UNHAS), Makassar, Indonesia for the moral and material assistance in the publication of this paper. The award is also intended for those who assist in the improvement of this manuscript.

\section{REFERENCES}

[1]. Amsler, C. D., and V.A. Fairhead. 2006. Defensive and sensory chemical ecology of brown algae. Advanced Botanical Research, 43: 1-91.)

[2]. Anggadireja. T., A. Zatnika, H. Purwoto, dan S. Istini. 2008. Rumput Laut. Penebar Swadaya. Jakarta .

[3]. Arnold, T. M., and N. M. Targett. 2002. Marine tannins: the importance of a mechanistic framework for predicting ecological roles, Journal of Chemical Ecology, 28(10):1919-1934.

[4]. Carlson, D. J., and L. M. Mayer. 1983. Relative influences of riverine and macroalgal phenolic materials on UV absorbance in temperate coastal waters, Canadian Journal of Fisheries and Aquatic Sciences, 40(8):1258-1263.

[5]. Chow, F. 2012. Nitrate Assimilation: The Role of In Vitro Nitrate Reductase Assay as Nutritional Predictor. In: Najafpour, M. 2012 (Ed.). Applied Photosynthesis. InTech. pp.105-120

[6]. DeBoer, J.A. 1979. Effects of Nitrogen Enrichment on Growth and Phycocolloid Content. In : Jensen, A and J.R. Stein (Eds.). 1979. Gracilaria foliifera and Neoagardhiella bailey (Florideophyceae). Proceed. Of the 9th
International Seaweed Symp. Sci.Press. Princeton,N.J. pp. 263-271.

[7]. Ditjenkan Budidaya, 2005. Profil Rumput Laut Indonesia. Ditjenkenbud. Dept. Kelautan dan Perikanan Republik Indonesia.Jakarta.

[8]. Dy D. T. and T.H. Yap. 2001. Surge ammonium uptake of the cultured seaweed, Kappaphycus alvarezii (Doty) Doty (Rhodophyta, Gigartinales). Journal of Experimental Marine Biology and Ecology, 265:89-100

[9]. Edwards, M.S and S. D. Connell. 2012. Competition, a Major Factor Structuring Seaweed Communities (Chapter 7). In Wiencke, $\mathrm{C}$ and K. Bischof (Eds.), Seaweed Biology, Ecological Studies 219, Springer-Verlag Berlin Heidelberg. Pp.136-156

[10]. Endo, H., K. Suehiro, J. Kinoshita, X. Gao, Y. Agatsuma. 2013. Combined Effects of Temperature and Nutrient Availability on Growth and Phlorotannins Concentration of the Brown Alga patens (Fucales; Phaeophyceae) American Journal of Plant Sciences, 4 (12B), 7 pp.

[11]. Glenn E. P. and M.S. Doty. 1990. Growth of the seaweeds Kappaphycus alvarezii, K. Striatum and Eucheuma denticulatum as affected by environment in Hawaii. Aquaculture, 84:245255.

[12]. Glenn, E.P. and M.S., Doty, 1992. Water motion affects the weight gains of Kappaphycus alvarezii and related seaweeds. Aquaculture 108:233 - 246.

[13]. Gupta, S., and N. Abu-Ghannam. 2011. Bioactive potential and possible health effects of edible brown seaweeds. Trends in Food Science \& Technology, 22:315-326.

[14].Harrison, P.J. and C.L. Hurd. 2001. Nutrient physiology of seaweeds: Application of concepts to aquaculture. Cah. Biol. Mar., 42: 71-82..

[15].Hurd, C.L., C.L. Stevens, B.E.Laval, G.A.Lawrence, and P.J.Harrison. 1997. Seawater Flow Around Morphologically Distinct Forms of 
the Giant Kelp Macrocystis integrifolia from Wave -sheltered and exposed sites. Limnol. Oceanogr. 42: 156-163.

[16]. Hwang, E.K., Ay-Lin, R.L., C. Tsai, T. Lee. 2004. Assessment of Temperature and Nutrient Limitation on Seasonal Dynamics Among Species of Sargassum From a Coral Reef in Southern Taiwan. J. of Phycol. 40(3): 463-473

[17].Kadam, S.U., C.Alvarez, B.K. Tiwari, C.P. O'Donnel. 2015. Extraction of Biomolecule From Seaweeds. http://doi.org/10.1016/B978-012-418697-2.00009-X

[18]. Kim, S.K.and I. Wijesekara. 2011. Anticoagulant Effect of Marine Algae. http://doi.org/10.1016/B978-0-12-3876690.00018-1

[19]. Koivikko, R., J. Loponen, T. Honkanen, and V. Jormalainen. 2005. Contents of soluble, cellwall-bound and exuded phlorotannins in the brown alga Fucus vesiculosus, with implications on their ecological functions, Journal of Chemical Ecology, 31(1): 195-212.

[20]. Kotiya, A.S., B. Gunalan, H.V. Parmar, M. Jaikumar, D. Tushar, B. Solanki Jitesh and N. P. Makwana. 2011. Growth comparison of the seaweed Kappaphycus alvarezii in nine different coastal areas of Gujarat coast, India. Advances in Applied Science Research, 2011, 2 (3):99-106

[21]. Lapointe, B.E. and J.H.Ryther. 1979. The Effects of Nitrogen and Seawater Flow Rate on the Growth and Biochemical Composition of Gracilaria foliifera v.Angustissima in Mass Outdoor Culture. Bot.Mar. 22 :529-537

[22]. Maina, M. H. 2014. Structural Investigation of the Natural ProductsComposition of Selected South African Seaweeds. Ph.D. Dissertation, Department of Chemistry, Faculty of Natural Sciences University of the Western Cape. 282 pp [23]. Michelon, M. L. B. Da Silva, M.P. Mezzari, M. Pirolli1, J. M. Prandini, and H. M.Soares. 2016. Effects of Nitrogen and Phosphorus on Biochemical Composition of Microalgae
Polyculture Harvested from Phycoremediation of Piggery Wastewater Digestate. Appl. Biochem Biotechnol., 178(7):1407-1419

[24]. Neish I. C. 2005. The Eucheuma seaplant handbook. Volume I, Agronomics, Biology and Crop System. SeaPlantNet. Technical Monograph No. 0505-10A, Makassar.

[25]. Neish, A.C. and P.F. Shacklock. 1971. Green House Experiments on the Propagation of Irish Moss. Nation. Res. Council of Canada. Atlantic Regional. Lab. Halifax. N.S. Tech.Reg., 14. 35 pp [26]. Neish, A.C., P.F. Shacklock, C.H. Fox and F.J. Simpon. 1977. The Cultivaion of Chondrus crispus. Fators Affecting Gowth Under Green House Conditions. Can.J.Bot., 55:2263-2271

[27]. Ohno, M., and Orosco, C.A., 1987. Growth rate of three species of Eucheuma, commercial red algae from the Philippines. In I. Umezaki (ed.), Scientific Survey of Marine algae and their Resources in the Philippine Islands. Privately published by the Laboratory of Fishery Resources, Graduate School of Agriculture, Kyoto University, Japan. pp. 77-81.

[28]. Prihaningrum A., M. Meiyana dan Evalawati. Tahun 2001. Biologi Rumput laut; Teknologi Budidaya Rumput Laut (Kappaphycus alvarezii). Petunjuk Tekhnis. Departemen Kelautan dan Perikanan. Direktorat Jenderal Perikanan Budidaya. Balai Budidaya Laut. Lampung, Indonesia. 66 pp.

[29]. Ragan, M. A., and A. Jensen. 1978. Quantative studies on brown algal phenols II. Seasonal variation in polyphenol content of Ascophylum nodosum (L) and Fucus vesiculosus (L). Journal of Experimental Marine and Biology Ecology, 34: 245-258.

[30]. Raikar, V. and M. Wafar. 2006. Surge ammonium uptake in macroalgae from a coral atoll. Journal of Experimental Marine Biology and Ecology, 339:236-240

[31]. Rao, A.S and M.U. Rao. 2002. Seasonal Growth Pattern in Sargassum polycystum C.Agardh 
(Phaeophyta, Fucales) Occuring at Visakhapatnam, East Coast of India. Indian J. Mar. Sci., 31(1):26-32

[32]. Rui, Li, L.Jiajun and W.Chaoyuan. 1990. Effects of Ammonium on Growth and Carrageenan Content of Kappaphycus alvarezii (Gigartinales, Rhodohyte). Hydrobiol., 204/205:499-502

[33]. Schoenwaelder, M. E. A., and M. N. Clayton. 1998. Secretion of phenolic substances into the zygote wall and cell plate in embryos of Hormosira and Acrocarpia (Fucales, Phaeophyceae). Journal of Phycology, 34: 969980.

[34]. Singh, J.P. and J.Sidana. 2014. 5 - Phlorotannins. National Institute of Pharmaceutical Education and Research (NIPER), India. https://doi.org/10.1533/9780857098689.1.181

[35]. Steinberg, C. E. W. 2011. Stress EcologyEnvironmental Stress as Ecological Driving Force and Key Player in Evolution. Springer. $480 \mathrm{pp}$.

[36]. Sudjiharno, 2001. Teknologi Budidaya Rumput Laut. Balai Budidaya Laut. Lampung, Indonesia. $91 \mathrm{pp}$.

[37]. Swanson, A. K., and L. D. Drueh. 2002. Induction, exudation and the UV protective role of kelp phlorotannins, Aquatic Botany, 73:241253.

[38]. Swamy, M.L.A. 2011. Marine Algal Sources for Treating Bacterial Diseases. https://doi.org/10.1016/B978. 0-12- 3876690.00006-5

[39]. Vergara, J. J., J .A Berges, and P. G. Falkowski. 1998. Diel periodicity of nitrate reductase activity and protein levels in the marine diatom Thalassiosira weissflogii (Bacillariophyceae). J. Phycol. 34: 952-961.

[40].Xiao Zou, S., S. Shan Xing, J.Zhu, J.Qin Huang, and S.Xiang Bao. 2017. The Effects of Temperature, Salinity, and Irradiance Upon the Growth of Sargassum polycystum C.Agard
(Phaeophyceaee). J.of App. Phycol. In Press, 26 September 2017: 1 - 9

[41].Zatnika, A. 2009. Pedoman Teknis Budidaya Rumput Laut. Badan Pengkajian dan Penerapan Teknologi, Jakarta, Indonesia.

\section{Cite this article as :}

Rajuddin Syamsuddin, Ridwan Bohari, Saparuddin, "Weight Gain of Seaweed Kappaphycus aalvarezii (Rhodophyta, Solierisceae) and Sargassum polycystum (Paeophyta, Sargassaceae) Mix Cultured at Different Planting Distances", International Journal of Scientific Research in Science and Technology (IJSRST), Online ISSN : 2395-602X, Print ISSN : 2395-6011, Volume 6 Issue 1, pp. 473-479, January-February 2019. Available at doi : https://doi.org/10.32628/IJSRST196162 Journal URL : http://ijsrst.com/IJSRST196162 